\title{
Impact of a program to promote health and quality of life of elderly
}

\author{
Impacto de um programa de promoção da saúde na qualidade de vida do idoso
}

\author{
Silvia Affini Borsoi Tamai ${ }^{1}$, Sergio Márcio Pacheco Paschoal ${ }^{1}$, Julio Litvoc ${ }^{2}$, Adriana Nunes Machado ${ }^{1}$, \\ Pedro Kallas Curiati ${ }^{2}$, Luis Felipe Prada ${ }^{1}$, Wilson Jacob-Filho ${ }^{1}$
}

\begin{abstract}
Objective: To evaluate the effect on quality of life of elderly people enrolled in GAMIA - Multidisciplinary Care Group to Outpatient Elderly Subjects (Grupo de Assistência Multidisciplinar ao Idoso Ambulatorial) of the Geriatric Department, Hospital das Clinicas, Faculdade de Medicina, Universidade de Sao Paulo. Methods: Between 2000 and 2002, 83 elderly participants of GAMIA were assessed by the World Health Organization Quality of Life scale (WHOOOL-bref) at the beginning and the end of the program. Functionality was assessed by Katz and Lawton scales and sociodemographic data were obtained from medical charts. Results: Females predominated $(79.5 \%)$ and overall mean age was 69.30 years. Data analysis showed a reduction in the physical domain of WHOOOL-bref $(p=0.014)$ and increased psychological health and environment domains $(p=0.029$ and $p=0.007$, respectively), detecting a trend of increase in social relationships and in general domains $(p=0.062$ and $p=0.052$, respectively). Conclusions: The clinical evaluation of the elderly detected previously unknown diseases and determination of the use of new drugs, which might have been the predominant factor for the deterioration of their perception in the physical domain. Improvement in psychological health and the environment can be related to psychological and social support that the elderly received from peers and professionals and the benefits of group activities, as well as the upward trend observed in social relationships and general domains. Participation in a program to promote healthy aging was effective in improving the quality of life of the elderly.
\end{abstract}

Keywords: Aged; Quality of life; Health promotion; Questionnaires; Aging

\section{RESUMO}

Objetivo: Avaliar os efeitos na qualidade de vida de idosos matriculados no Grupo de Assistência Multidisciplinar ao Idoso Ambulatorial (GAMIA) do Serviço de Geriatria do Hospital das Clínicas da Faculdade de Medicina da Universidade de São Paulo. Métodos: Nos 83 idosos participantes do grupo entre 2000 e 2002, a qualidade de vida foi avaliada pelo World
Health Organization Quality of Life (WHOOOL-bref) no início e no fim do programa. A funcionalidade foi avaliada pelas Escalas de Katz e Lawton e os dados sociodemográficos foram obtidos nos prontuários. Resultados: Houve predomínio do sexo feminino $(79,5 \%)$ e a média geral de idade foi de 69,30 anos. A análise dos dados mostraram uma redução no domínio físico do WHOQOL-bref $(p=0,014)$ e a elevação dos domínios psicológico e meio ambiente ( $p=0,029$ e $p=0,007$, respectivamente), detectando-se tendência de elevação nos domínios relações sociais e geral ( $p=0,062$ e $p=0,052$, respectivamente). Conclusões: Como a avaliação clínica desses idosos revelou doenças desconhecidas previamente e determinou a utilização de novos medicamentos, a percepção que os idosos tinham, em relação à sua saúde, pode ter sido o fator preponderante para a piora no domínio físico. A melhora dos domínios psicológico e meio ambiente pode estar relacionada ao suporte psicológico e social que o idoso recebeu dos colegas e profissionais e dos benefícios das atividades em grupo, bem como às tendência de elevação observada nos domínios relações sociais e geral. A participação em um programa de promoção do envelhecimento saudável mostrou-se eficaz na melhora da qualidade de vida do idoso.

Descritores: Idoso; Qualidade de vida; Promoção da saúde; Questionários; Envelhecimento

\section{INTRODUCTION}

Live longer, but with quality: this is what most people who understand aging as a process and realize elderly age is a fact want to have, based on demographic studies that have suggested a 25-year increase in life expectancy for Brazilians in the past 50 years ${ }^{(1)}$.

As a result of the epidemiological transition that follows demographic transition, there has been a reduction in infectious and contagious diseases and an increase in prevalence of chronic non-communicable

\footnotetext{
Study carried out at Geriatriacs Outpatient Clinic, Hospital das Clínicas, Faculdade de Medicina, Universidade de São Paulo - USP, Sao Paulo (SP), Brazil.

'Hospital das Clinicas, Faculdade de Medicina, Universidade de São Paulo - USP - São Paulo (SP), Brasil.

2 Faculdade de Medicina, Universidade de São Paulo - USP - São Paulo (SP), Brasil.

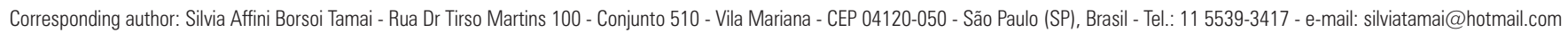

Received: Jul 08, 2010 - Accepted: Jan 24, 2011

There is no conflict of interest.
} 
diseases, which has led to a greater proportion of elderly people with these diseases. In view of this picture, longevity provides an ambiguous situation experienced by many people (less for non-elderly people), which is the will to live longer and, at the same time, the fear to live with disability and dependence ${ }^{(2)}$.

Aware of this change and the importance of planning public policies for this population, professionals who work with aging have started to plan and to develop global actions that fostered health of the elderly within the perspective of health promotion. According to the Ottawa Charter for Health Promotion ${ }^{(3)}$, "health promotion is the political and social process that encompasses not only actions to strengthen skills and capabilities, but also those directed to changing social, environmental and economic status, to attenuate the impact on public and individual health."

Ten years after the publication of the Ottawa Charter, the Fourth International Conference on Health Promotion was held in Jakarta. The Jakarta Declaration on Leading Health Promotion ${ }^{(4)}$ reinforced the concept of health promotion and encouraged the participation of the community. The proposal was to train the population to lead and to access available health resources.

Two years before the Ottawa Charter, the activities of GAMIA - Multidisciplinary Care Group to Outpatient Elderly Subjects of the Geriatrics Department, Hospital das Clinicas, Faculdade de Medicina, Universidade de Sao Paulo (FMUSP) were started, formed by a multidisciplinary team. At that time, the program creator, Prof Dr Wilson Jacob Filho, came up with the term senesculture ${ }^{(5)}$ as being the "set of interdisciplinary actions whose results contribute to promoting the health in the elderly", a concept that was used to characterize the whole activities of this professional group.

Therefore, o Grupo de Assistência Multidisciplinar ao Idoso Ambulatorial (GAMIA) structured a pioneer work at the time, designing group sessions for previously selected elderly subjects who would come to the Geriatric Outpatient Center weekly to perform activities that aimed to promote health and comprised medical visits, specialized guidance and physical, social and leisure activities.

GAMIA is a group searching for knowledge about health. The activities are based on the fact that the elderly need to know about their health status and alternative treatment options and to be able to decide about their health ${ }^{(6)}$. Providing instruments for the elderly to learn about their rights and duties means to develop citizenship and promote access to the integrated health model.

Currently, the team counts on a group of professionals formed by nurses, pharmacists, physical therapists, physicians, psychologists, social workers and occupational therapists. GAMIA selects 30 elderly subjects to take part in the annual program based on a screening tool applied to those that are interested in participating, incorporating the following inclusion criteria: both sexes, age equal or over 60 years, independent locomotion, communication skills that enable group participation, and interest in and commitment to the program ${ }^{(7)}$.

The 30 selected elderly subjects are divided into two groups of 15 people and start to come to the Geriatric Outpatient Center every wednesday, from 8 am to $3 \mathrm{pm}$. All activities are in group, except for medical visits. The

Chart 1. Flowchart of activities of GAMIA in 2010 - Groups Yellow and Green

\begin{tabular}{|c|c|c|c|c|c|c|c|c|c|c|c|c|c|c|}
\hline \multicolumn{4}{|c|}{ TIME } & \multicolumn{3}{|c|}{ SEQUENCE A } & \multicolumn{4}{|c|}{ TIME } & \multicolumn{4}{|c|}{ SEQUENCE B } \\
\hline \multicolumn{4}{|c|}{$8 a m-9 a m$} & \multicolumn{3}{|c|}{ NUTRITION } & \multicolumn{4}{|c|}{$8 a m-9 a m$} & \multicolumn{4}{|c|}{ PHARMACY } \\
\hline \multicolumn{4}{|c|}{$9 a m-10 a m$} & \multicolumn{3}{|c|}{ SOCIAL WORKER } & \multicolumn{4}{|c|}{$9 \mathrm{am}-10 \mathrm{am}$} & \multicolumn{4}{|c|}{ PHYSICAL THERAPY } \\
\hline \multicolumn{4}{|c|}{$10 a m-11 a m$} & \multicolumn{3}{|c|}{ PHYSICAL THERAPY } & \multicolumn{4}{|c|}{$10 \mathrm{am}-11 \mathrm{am}$} & \multicolumn{4}{|c|}{ PSYCHOLOGY } \\
\hline \multicolumn{4}{|c|}{$11 \mathrm{am}-12: 30 \mathrm{pm}$} & \multicolumn{3}{|c|}{ LUNCH } & \multicolumn{4}{|c|}{$11 \mathrm{am}-12 \mathrm{pm}$} & \multicolumn{4}{|c|}{ LUCH } \\
\hline \multicolumn{4}{|c|}{$12: 30 p m-1: 30 p m$} & \multicolumn{3}{|c|}{ NURSING } & \multicolumn{4}{|c|}{$12 \mathrm{pm}-1 \mathrm{pm}$} & \multicolumn{4}{|c|}{ OCCUPATIONAL THERAPY } \\
\hline \multicolumn{4}{|c|}{$1: 30$ pm - 3 pm } & \multicolumn{3}{|c|}{ OCCUPATIONAL THERAPY } & \multicolumn{4}{|c|}{$1 p m-2 p m$} & \multicolumn{4}{|c|}{ MEDICAL APPOINTMENT } \\
\hline 03 & Introd & ction & 07 & $A$ & B & 05 & B & $A$ & 02 & A & $\mathrm{B}$ & 07 & B & $A$ \\
\hline 10 & A & B & 14 & B & $A$ & 12 & A & B & 09 & B & A & 14 & A & B \\
\hline 17 & B & A & 21 & Hol & & 19 & & & 16 & A & B & 17 & GAMIA anr & jersary day \\
\hline 24 & $A$ & B & 28 & A & B & 26 & B & A & 23 & B & A & & dd 28 - Vace & ions \\
\hline 31 & B & A & & & & & & & 26 & Folk & arty & & & \\
\hline 04 & $B$ & $A$ & 01 & $B$ & $A$ & 01 & Elder & Day & 03 & $B$ & $A$ & 01 & $\mathrm{~A}$ & \\
\hline 11 & A & B & 8 & A & B & 06 & A & B & 10 & A & B & 11 & Christm & s Party \\
\hline 18 & B & A & 15 & B & A & 13 & B & A & 17 & B & A & & & \\
\hline 25 & A & B & 22 & A & B & 20 & & & 24 & A & B & & & \\
\hline & & & 29 & B & A & 27 & A & B & & & & & & \\
\hline
\end{tabular}


two groups happen concomitantly on wednesdays. The areas of physical therapy and occupational therapy see the groups on a weekly basis and the other areas take turns in each group every fifteen days. A sample of the scheduled activities can be seen in Chart 1.

The elderly take part in social and leisure activities together with the elderly subjects in the Post-GAMIA group, formed by elderly subjects who had participated in GAMIA before, including sight visiting, parties and trade fairs.

Since 2002, the elderly have been editing the GAMIA News, of which committee is formed by elderly from GAMIA, Post-GAMIA and the social worker. The objective of this activity is to stimulate and provide the opportunity for the elderly to participate, while the professional works as facilitator and collaborator. GAMIA News is an open space for interviews, articles on prevention and health, topics related to the elderly, hints, recipes, jokes, news about the groups; in other words, a vehicle for participation.

Thinking about aging as a positive experience shows the position that the World Health Organization (WHO) calls active aging ${ }^{(8)}$ : "the process of optimizing healthcare opportunities, participation and safety, to improve quality of life as people get older".

Quality of life should be understood ${ }^{(9)}$ as "the perception that the subject has about life within the context of culture and the value system where he lives and in relation to his objectives, expectations, standards and concerns".

\section{OBJECTIVE}

The purpose of the present study was to check whether there had been any changes to quality of life of the elderly who participated in GAMIA.

\section{METHODS}

The study was carried out at the Geriatric Outpatient Center, Hospital das Clinicas, FMUSP, with elderly patients who took part in GAMIA program during the years 2000, 2001 and 2002. There were 83 people observed for one-year follow-up using the quality of life tool World Health Organization Quality Of Life (WHOQOL-bref), applied at the beginning and at the end of the program. The study was concluded with 83 out of 90 people with two completed assessments.

The selected tool, the WHOQOL-bref, is an abbreviated version of WHOQOL-100, both validated for the Brazilian population ${ }^{(10,12)}$. WHOQOL-Bref comprises the 26 best questions in the psychometric performance, covering four specific domains (physical, psychological, social relations and environment) and one general domain.

This tool was developed by the WHO in a multicenter study, based on the assumption that quality of life is a multidimensional subjective construction (perception of the subject) and comprises positive elements (such as mobility) and negative elements (pain) ${ }^{(13)}$.

Social demographic data were extracted from a questionnaire designed by the author and by information included in the patient charts.

To measure the indexes that assessed daily living activities we used Katz Basic Activities of Daily Living (ADL) and Instrumental Activities of Daily Living (IADL) by Lawton.

Katz scale assesses basic ADL (14,15). The activities are divided into items such as showering, eating, personal hygiene, getting dressed, movement and continence. The total score is determined by the sum of affirmative answers and a maximum of six points means full independence for basic ADLs.

Lawton scale assesses instrumental activities of daily living ${ }^{(16)}$. The activities are divided into using the phone, going to distant places, going shopping, preparing the meals, cleaning the house, doing domestic errands, washing and ironing the clothes, taking medication, and taking care of money. For each question, the first answer means independence, the second one means the person can do it with help, and the third one is dependence. The maximum score is 27 points and the score is meaningful only to the individual patient, serving as a basis for progressive comparisons.

To meet the objectives of the study, we used differences in quality of life of WHOQOL domains using matched Wilcoxon tests ${ }^{(17)}$ and the differences were calculated for each domain (final - baseline). The normal distribution of differences in domains was tested using KolmogorovSmirnov test ${ }^{(17)}$, which accepts the assumption of data distribution normal range $(\mathrm{p}>0.05)$. The tests were carried out with a significance level smaller than $5 \%$.

The study was approved by the Ethics Committee for Research Projects (CAPPesq), Clinical Director, Hospital das Clinicas, Universidade de Sao Paulo, and the informed consent term was signed by all participants.

\section{RESULTS}

Out of 83 subjects, $79.5 \%$ were female and $20.5 \%$ were male and the mean age was 69.30 years.

Katz scale showed that all elderly subjects obtained maximum score, whereas in Lawton scale, $92.8 \%$ obtained maximum score (Table 1).

Table 1. Description of activities of daily living scores

\begin{tabular}{lccc}
\hline Scale & $\mathbf{N}$ & Score & $\%$ \\
\hline KATZ & 83 & 6 & 100 \\
LAWTON & 1 & 24 & 1.2 \\
& 2 & 25 & 2.4 \\
& 3 & 26 & 3.6 \\
& 77 & 27 & 92.8 \\
\hline
\end{tabular}


Table 2. Description of quality of life scores at baseline and end of the program and result of comparison of the two timeframes

\begin{tabular}{|c|c|c|c|c|c|c|c|c|}
\hline Domain & Time & Mean & SD & Median & Minimum & Maximum & $\mathbf{N}$ & p value \\
\hline \multirow{2}{*}{ Physical } & Baseline & 71.08 & 16.31 & 75.0 & 28.6 & 100.0 & 83 & \multirow{2}{*}{0.014} \\
\hline & One year & 68.46 & 15.76 & 67.9 & 32.1 & 100.0 & 83 & \\
\hline \multirow{2}{*}{ Psychological } & Baseline & 66.41 & 15.65 & 66.7 & 29.2 & 100.0 & 82 & \multirow{2}{*}{0.029} \\
\hline & One year & 70.08 & 13.00 & 70.8 & 41.7 & 100.0 & 83 & \\
\hline \multirow{2}{*}{ Social relations } & Baseline & 65.75 & 16.36 & 66.7 & 25.0 & 100.0 & 82 & \multirow{2}{*}{0.062} \\
\hline & One year & 69.07 & 14.52 & 75.0 & 25.0 & 100.0 & 83 & \\
\hline \multirow{2}{*}{ General } & Baseline & 63.86 & 16.68 & 62.5 & 25.0 & 100.0 & 83 & \multirow{2}{*}{0.052} \\
\hline & One year & 67.62 & 15.38 & 75.0 & 25.0 & 100.0 & 83 & \\
\hline
\end{tabular}

SD: Standard deviation

Table 2 shows that people participating in GAMIA program had statistically significant reduction in physical domain $(\mathrm{p}=0.014)$ and improved psychological and environment domains $(\mathrm{p}=0.029$ and $\mathrm{p}=0.007$, respectively). Social relations and general domains showed improvement trends.

\section{DISCUSSION}

Considering the selection criteria, participants in GAMIA program were characterized as being independent elderly subjects in relation to daily living activities and they were cognitively preserved, showing full autonomy.

Kalache et al. ${ }^{(18)}$ observed that the maintenance of autonomy was closely related with quality of life and a way to quantify this variable would be the level of autonomy with which the subject performed his everyday activities, making him independent in his cultural and social economic context. In practice, an appropriate way to measure these characteristics would be the performance of daily living activities.

Physical domain assesses the aspects related with pain and discomfort, energy and fatigue, sleep and rest, daily living activities, dependency on medication or treatment, in addition to capacity to work.

The decrease observed in scores of physical domain may be related with the perception the elderly acquired of their health status owing to the discovery and the awareness of new diagnoses, and consequently, of the need for new treatments. However, it is not indicative that their health status had worsened in the period.

A study by Xavier et al. ${ }^{(19)}$ showed that elderly subjects dissatisfied with their quality of life had more health problems according to the Cumulative Illness Rating Scale (CIRS) and more depressive symptoms when assessed by the Geriatric Depression Scale (GDS); the reason for this dissatisfaction was lack of physical health. It was concluded that the concept of negative quality of life would be equivalent to loss of health, whereas the concept of positive quality of life would be equivalent to a multitude of categories, such as activity, income, social life and relationship with the family, categories that varied from subject to subject.

The revision by Fortin et al. ${ }^{(20)}$ showed that there is an inverse relation between multiple morbidities and quality of life, observed also in the study by Miranda et al. ${ }^{(21)}$. In both studies, people had stabilized chronic diseases, did not show functional limitations, pain or complications. Data suggested that the patients with this profile, when aware of their real health status, changed their perception in relation to physical health and, consequently, their assessment of quality of life.

Owing to multidisciplinary care, the elderly have learned that there are other approaches, such as healthy nutrition, physical activities, care with the health, psychotherapy, and occupational therapy, that work as a powerful support to medical treatment.

Non-medication approaches require the adoption of new habits and behavioral changes, modifying their routines. These changes may be difficult because they depend on compliance of the elderly and the multidisciplinary team plays a key role in this aspect.

The psychological domain assesses the aspects related with positive and negative feelings, thinking, learning, memory and concentration, self-esteem, body image and appearance, spirituality/religiousness/ personal beliefs. The improvement observed in this domain may be related with many different factors.

Upon joining GAMIA, the elderly feel welcome owing to the support that the group work provides and the feeling that there are professionals available and interested in helping them address different aspects related with aging. There is also the possibility of making new friends, contributing to self-esteem and positive feelings related with aging.

The dynamics resulting from the multidisciplinary care enhanced the relationship between the professional team and collaborated to make the elderly subjects 
change their concepts and behaviors in relation to the aging process and their condition as old people.

Similarly, group sessions also influence the environment domain, which assesses the aspects related with physical safety and protection, home environment, financial resources, health and social care (availability and quality), opportunities to acquire new information and skills, participation/opportunities of recreation/ leisure, physical environment (pollution/noise/traffic/ weather) and transportation.

The commitment to participate periodically in GAMIA program activities made the elderly realize the importance of having time for themselves.

Knowledge and the perception of these flaws provided adaptive and strengthening responses, capable of maximizing the performance of the elderly in their social world and providing active and acting permanence in it ${ }^{(22)}$.

The elderly share their own perceptions and the perceptions of others, which may expand their family, friend and social relationships ${ }^{(22)}$.

The domain of social relations assesses the aspects concerning personal relations, social support and sexual activity. It is believed that the improvement trend observed in this domain resulted from greater perception of the elderly concerning their possibility of articulation and affective relationships acquired by the group activities, a fundamental support of GAMIA program.

The literature ${ }^{(23-25)}$ points to a key issue observed in personal relations in large cities. Factors such as high demographic density, heterogeneity of the population, poor security and adaptation of public spaces do not stimulate personal and social growth of their members, because they hinder interaction and leisure opportunities.

It is difficult to organize spaces where the elderly can practice citizenship and interaction, encouraging their social participation. Therefore, group activities contribute to the performance of new roles and the readaptation of others that had been abandoned throughout life.

According to Lima and Pasetchny(23), difficulties in interpersonal and social interactions in large cities, associated with lack of public spaces and increase in number of elderly subjects, require the creation of elderly groups because they support social inclusion of the elderly.

Similarly, in the general domain, which refers to selfperception of quality of life and level of satisfaction with health, it is believed that the improvement trend was owed to better knowledge of their skills and capabilities, but in agreement with the recently acquired awareness of diseases and limitations, resulting from the accurate process of global geriatric assessment.

The longitudinal study carried out by Rudinger and Thomae (apud Neri) ${ }^{(26)}$ provided valuable information about adjustment and satisfaction in elderly life, emphasizing that the perceived health and the way people handle their health problems were more predictive than objective health conditions, assessed according to medical parameters.

The fact that elderly subjects were referred to GAMIA screening program by former GAMIA elderly subjects, dispensing communication efforts by the Geriatric Department, shows the positive influence of the program on the elderly routine, which started to play a role as multiplying agent. Post-GAMIA elderly patients want their family members, neighbors and friends to benefit as much as they have.

According to Melo et al. ${ }^{(27)}$, in any healthcare system, no action plan shall be designed without taking into account the assumptions of the educative planning.

The WHO states that the objective of health education is to develop in people the notion of responsibility for their own health and for the health of the community they belong, and the capacity to take part in the community life in a constructive fashion. These assumptions transform health education into one of the most important links between wishes and expectations of the population for a better life, in addition to projections and estimates of government authorities when providing more efficient health programs ${ }^{(28)}$.

The group work with elderly serves as a tool to autonomy and continuous development of health and life conditions, promoting the health of elderly subjects ${ }^{(27)}$.

The care model proposed by the professional team at GAMIA may be reproduced in the public health network, because its structure is simple and low cost, considering that it has worked for 26 years in the Geriatric Center, at Hospital das Clinicas, FMUSP.

Therefore, actions directed to promoting healthy aging break with the elderly care paradigm, which has focused primarily on symptomatic management of diseases. We believe in the importance of models that allow aging people to take active roles in the construction of their future, concepts that have been well synthesized by Litvoc and Brito ${ }^{(29)}$, highlighting that prevention and health promotion actions that include the measures referring to diseases and aspects of social and cultural wellbeing are essential for the elderly with preserved functional capability, as well as for those already disabled. In the case of elderly subjects with preserved function, these actions are necessary to maintain intact functional status. 


\section{CONCLUSION}

Even though the literature relates the importance of physical health in the development of good quality of life in the elderly, this study has shown that despite the decrease in physical domain scores, the elderly had improvement in quality of life owing to the development of psychological, social and environmental support.

\section{REFERENCES}

1. Ramos LR. Epidemiologia do Envelhecimento. In: Freitas EV, PY L, Cançado FAX, Gorzoni ML. Tratado de geriatria e gerontologia. Rio de Janeiro: Guanabara Koogan; 2002. p.72.

2. Paschoal SMP. Qualidade de vida na velhice. In: Freitas EV, PY L, Cançado FAX, Gorzoni ML. Tratado de geriatria e gerontologia. Rio de Janeiro: Guanabara Koogan; 2002. p.79.

3. World Health Organization (WHO). The Otawa Charter for Health Promotion, 17-21 November 1986.

4. World Health Organization (WHO). Jacarta Declaration on Leading Health Promotion into the 21 st century, 21-25 July, 1997.

5. Jacob-Filho W. Promoção da saúde do idoso. São Paulo: Lemos; 1998.

6. Viude A. Atividade de fonoaudiologia. In: Jacob-Filho W. Prática a caminho da senecultura - Grupo de Assistência Multidisciplinar ao Idoso Ambulatorial, GAMIA. São Paulo, Atheneu, 2003. p.49.

7. Jacob-Fllho W. Prática a caminho da senecultura - Grupo de Assistência Multidisciplinar ao Idoso Ambulatorial, GAMIA. São Paulo: Atheneu; 2003.

8. World Health Organization (WHO). Active Ageing. A Policy Framework. Madrid, Spain, 2002.

9. The WHOQOL Group. The World Health Organization Quality of Life assessment (WHOQUOL): position paper from the World Health Organization. Soc Sci Med. 1995;10(41):1403-9.

10. Fleck MPA, Chachamovich E, Louzada S, Pinzon V, Vieira G. Aplicação da versão em português do instrumento de avaliação de qualidade de vida da Organização Mundial de Saúde (WHOOOL - 100). Rev Saúde Púb. 1999;33(2): 198-205.

11. Fleck MPA, Louzada S, Chachamovich E, Vieira G, Santos L, Pinzon V. Aplicação da versão em português do instrumento abreviado de avaliação de qualidade de vida "WHO0OL-Bref". Rev. Saúde Públ. 2000;34(1)0: 178-83.
12. Fleck MPA. 0 instrumento de avaliação de qualidade de vida da Organização Mundial da Saúde (WHO0OL-100): características e perspectivas. Ciência e Saúde Coletiva. 2000;5(1):33-8.

13. Minayo MCS, Hartz ZMA, Buss PM. Qualidade de vida: um debate necessário. Ciência e Saúde Coletiva. 2000;5(1):7-18.

14. Katz S, Akpomk CA. A measure of primary sociobiological functions. Int J Health Serv. 1976;6(3):493-508.

15. Katz S, Ford AB, Moskowitz RW, Jackson BA, Jaffee MW. Studies of ilness in the aged. The Index of ADL: a standardized measure of biological and psychosocial function. JAMA. 1963;185:914-9.

16. Lawton MP, Brody EM. Assessment of older people: Self maintaining and instrumental activities of daily living. Gerontologist. 1969;9: $179-86$.

17. Conover W J . Practical nonparametric statistics. New York, Wiley, 1980.

18. Kalache A, Veras RP, Ramos LR. 0 envelhecimento da população mundial. Um desafio novo. Rev Saúde Públ. 1987;21(3):200-10.

19. Xavier FMF, Ferraz MPT, Marc N, Escosteguy NU, Moriguchi EH. Elderly peoples definition of quality of life. Rev Bras Psiquiat. 2003;25(1):37-49.

20. Fortin M, Lapoint L, Hudon C, Vanasse A, Ntetu ATL, Maltais D. Multimorbidity and quality of life in primary care: a systematic review. Health Qual Life Outcomes. 2004;2:51.

21. Miranda de Nóbrega TC, Jaluul O, Machado AN, Paschoal SMP, Jacob Filho W. Quality of life and multimorbidity of elderly outpatients. Clinics. 2009;64(1): 45-50.

22. Izzo H. Atividade de fisioterapia. In: Jacob-Filho W. Prática a caminho da senecultura - Grupo de Assistência Multidisciplinar ao Idoso Ambulatorial, GAMIA. São Paulo: Atheneu; 2003.

23. Lima LJC, Pasetchny. Atividades em grupo: uma alternativa para inclusão social na terceira idade. Rev Ter Ocup Univ São Paulo. 1998;9(1):37-42.

24. Schicchi MC. A arquitetura e os idosos: considerações para elaboração de projetos. SESC. 2000;xi(19):63-79.

25. Rolnik R. A cidade e o idoso. SESC. 1998:X(14):45-50.

26. Neri AL. Qualidade de vida e idade madura. Campinas: Papirus; 1993.

27. Melo MC, Souza AL, Leandro EL, Mauricio HA, Silva ID, Oliveira JMO. A educação em saúde como agente promotor da qualidade de vida para o idoso. Ciência e Saúde Coletiva. 2009;14(Supl.1):1579-86.

28. Levy SN, Silva JJC, Cardoso IFR, Werberich PM, Moreira LLS, Montiani H, et al. Educação em saúde: histórico, conceitos e propostas. Brasília, DF: Ministério da Saúde, 1997.

29. Litvoc J, Brito C. Prevenção e promoção da saúde. São Paulo: Atheneu; 2004. 